\title{
Organ-specific accumulation of selenium and mercury in Indo-Pacific bottlenose dolphins (Tursiops aduncus)
}

\author{
Masumi Marumoto $^{1 *} \mathbb{0}$, Mineshi Sakamoto ${ }^{1}$, Masaaki Nakamura' ${ }^{1}$, Kohji Marumoto ${ }^{1}$ and Shozo Tsuruta ${ }^{2}$
}

\begin{abstract}
Delphinids are top ocean predators and accumulate high concentrations of mercury $(\mathrm{Hg})$ through the food chain, particularly in organs such as liver and kidney, although the proportion of methylmercury (MeHg) is relatively low due to the demethylation process. Total mercury ( $\mathrm{T}-\mathrm{Hg}$ ) levels in marine mammals have been shown to correlate with selenium (Se) concentrations, and ingested MeHg that is demethylated may be present in tissues as mercury selenide (HgSe). In this study, we determined T-Hg, MeHg and Se concentrations of three Indo-Pacific bottlenose dolphins (Tursiops aduncus), and we used the individual with the highest $\mathrm{Hg}$ concentration for electron probe microanalysis to assess the co-localization of $\mathrm{Hg}$ and $\mathrm{Se}$ in the tissues. By electron probe microanalysis, we found that $\mathrm{Hg}$ and Se were co-localized in large granules in hepatic Kupffer cells and in small granules in hepatocytes. The analysis suggested that MeHg was demethylated in hepatocytes and then phagocytosed by Kupffer cells. In the kidney, Hg and Se were co-localized in the glomerular capillary wall and in interstitial blood vessel walls. Hg and Se were also co-localized in the cytoplasm of large neurons and in glial cells in the cerebrum. Divalent $\mathrm{Hg}$ and $\mathrm{HgSe}$ cannot cross the blood-brain barrier, suggesting that MeHg is demethylated in the dolphin brain and that binding to Se suppresses Hg toxicity.
\end{abstract}

Keywords: Distribution, Electron probe microanalysis, Inorganic mercury, Methylmercury, Trace elements

\section{Findings}

Delphinids are top ocean predators and accumulate mercury $(\mathrm{Hg})$ through the food chain $[1,2]$. $\mathrm{Hg}$ accumulates in high concentrations, particularly in liver and kidney [3], although the proportion of methylmercury (MeHg) is relatively small ( $10 \%$ or less) due to a demethylation process [4]. Total mercury $(\mathrm{T}-\mathrm{Hg})$ levels are typically co-localized and correlated with selenium (Se) concentrations [4] because Se has a high affinity for $\mathrm{Hg}[5,6]$. Se has been shown to protect against MeHg toxicity in whales and experimental animals $[7,8]$; in some species, ingested $\mathrm{MeHg}$ is converted to inorganic mercury (I-Hg),

*Correspondence: MASUMI_MARUMOTO@env.go.jp

${ }^{1}$ National Institute for Minamata Disease, 4058-18, Hama, Minamata, Kumamoto 867-0008, Japan

Full list of author information is available at the end of the article an insoluble $\mathrm{Hg}$ selenide mineral 'termed' tiemannite $[7,9]$. Therefore, in the liver, $\mathrm{Hg}$ and Se are present at a molar ratio of 1:1 in various whale species [10,11].

Photoemulsion histochemistry and autometallography method can be used to detect I-Hg in clinical samples $[12,13]$. However, as there is no way to visualize Se bound to I-Hg, histological localization of Se has not been elucidated. Electron probe microanalysis visualizes the distribution of trace elements in tissue sections [14, 15], and has been used to detect the distribution of trace elements in the tissues of patients with primary biliary cirrhosis, Minamata disease, Wilson's disease, and occupational lung diseases [14-17]. Electron probe microanalysis can localize trace elements at the level of specific cell types [14-17]. Sakamoto et al. reported the localization of Se and $\mathrm{Hg}$ in the skeletal muscle of a dolphin [8], but their co-localization in organs other than skeletal 
muscle has not been clarified. In this study, we analyzed the $\mathrm{Hg}$ and Se concentrations in the tissues of three IndoPacific bottlenose dolphins (Tursiops aduncus) and we used the individual with the highest $\mathrm{Hg}$ concentration for electron probe microanalysis to assess the co-localization of $\mathrm{Hg}$ and $\mathrm{Se}$ in the tissues.

Cryopreserved tissue samples of liver, kidney, lung, skeletal muscle, tail (bone-free skin and connective tissue), cerebrum, and cerebellum of 3 adult female dolphins captured as food in the Pacific Ocean along the coast of main island of Japan in 2011 were used for analyses. $\mathrm{T}-\mathrm{Hg}$ concentrations were determined by cold vapor atomic absorption spectrophotometry, and $\mathrm{MeHg}$ concentrations were measured using gas-chromatography-electron capture detector, according to previously described methods [18]. The I-Hg concentration was calculated subtracting methylmecury from the $\mathrm{T}-\mathrm{Hg}$ concentration. Se concentrations were measured by an inductively coupled plasma mass spectrometer equipped with a collision cell (Agilent 7500ce; Agilent Technologies, Santa Clara, CA, USA) by IDEA Consultants, Inc. (Shizuoka, Japan). T-Hg in a standard reference material, DORM-2 (dogfish muscle; National Research Council of Canada, Ottawa, ON, Canada), was measured as a quality control, and the measurements were within the certified range of $4.64 \pm 0.26 \mu \mathrm{g} / \mathrm{g}$. The same standard reference material was used to measure $\mathrm{MeHg}$, which was within the certified range of $4.47 \pm 0.032 \mu \mathrm{g} / \mathrm{g}$. NIST 1577 (bovine liver; Gaithersburg, MD, USA) was used as a quality control for Se measurement, and the measurements were within the certified range of $0.73 \pm 0.06 \mu \mathrm{g} / \mathrm{g}$. T- $\mathrm{Hg}, \mathrm{MeHg}$ and $\mathrm{I}-\mathrm{Hg}$ concentrations and the relationship between molar inorganic $\mathrm{Hg}$ and $\mathrm{Se}$ in organs of dolphins are shown in Table 1 and Fig. 1, respectively. The molar ratios of inorganic $\mathrm{Hg}$ to $\mathrm{Se}$ is shown in Table 2. Hg concentrations were highest in the liver, and the molar ratios of $\mathrm{Hg}$ to $\mathrm{Se}$ were close to 1 in most of the organs. In the tail the molar ratios were between 0.02 and 0.08 , and only in the liver the molar rations where higher than 1.

For histopathological examination, cryopreserved tissues of the dolphin with the highest $\mathrm{Hg}$ concentration (case 1) were fixed in 10\% neutral buffered formalin. After fixation, a paraffin block was prepared according to a conventional method with ethanol and xylene and sliced into 3- $\mu \mathrm{m}$ serial sections with a microtome and stained with hematoxylin and eosin. There were no pathological findings in any of the tissues examined. Serial sections were affixed to a carbon sample stage (Niigata Science, Niigata, Japan), deparaffinized, and dried. The specimens were sputter-coated with carbon prior to elemental analysis. Scanning electron microscopy was performed to assess morphological changes, and energy-dispersive $\mathrm{X}$-ray spectroscopy was conducted to determine the elemental composition using an electron probe microanalyzer (JXA-8530F, JEOL, Tokyo, Japan) with an acceleration voltage of $15 \mathrm{kV}$. Next, we used electron probe microanalysis for elemental mapping of $\mathrm{Hg}$, Se, zinc (Zn), sulfur $(\mathrm{S})$, iron $(\mathrm{Fe})$, and copper $(\mathrm{Cu})$ with $256 \times 256$ pixel mapping. In order to clarify the pathological image, mapping of amino nitrogen and nucleotide phosphorus was carried out. The acceleration voltage and beam current were set to $15 \mathrm{kV}$ and $0.38 \mu \mathrm{A}$, respectively.

Figure 2a shows a compositional image of the liver in backscattered electron mode. The white granules suggesting metal accumulation were observed in large numbers as large granules in Kupffer cells and as fine granules in hepatocytes. Energy-dispersive X-ray spectroscopy showed $\mathrm{Hg}$ and $\mathrm{Se}$ in hepatocytes (Fig. 2b) and $\mathrm{Hg}, \mathrm{Se}, \mathrm{Zn}, \mathrm{S}, \mathrm{Fe}$, and $\mathrm{Cu}$ in Kupffer cells (data not shown). Elemental mapping also showed that $\mathrm{Hg}$ and $\mathrm{Se}$ were deposited in hepatocytes, and their distribution was almost identical (Fig. 3). Large aggregation of $\mathrm{Hg}$ and $\mathrm{Se}$ were observed in Kupffer cells than in hepatocytes. $\mathrm{Hg}$, $\mathrm{Se}, \mathrm{Zn}, \mathrm{S}, \mathrm{Fe}$, and $\mathrm{Cu}$ were deposited in Kupffer cells

Table 1 Concentrations of total mercury ( $\mathrm{T}-\mathrm{Hg})$, methylmercury (MeHg) and inorganic mercury (I-Hg) in tissues from bottlenose dolphins

\begin{tabular}{|c|c|c|c|c|c|c|c|c|c|}
\hline & \multicolumn{3}{|c|}{ Case 1} & \multicolumn{3}{|c|}{ Case 2} & \multicolumn{3}{|c|}{ Case 3} \\
\hline & $\mathrm{T}-\mathrm{Hg}$ & $\mathrm{MeHg}$ & $\mathrm{I}-\mathrm{Hg}$ & $\mathrm{T}-\mathrm{Hg}$ & $\mathrm{MeHg}$ & $\mathrm{I}-\mathrm{Hg}$ & $\mathrm{T}-\mathrm{Hg}$ & $\mathrm{MeHg}$ & $\mathrm{I}-\mathrm{Hg}$ \\
\hline Liver & 1930 & 13.0 & 1917 & 662 & 11 & 651 & 534 & 17 & 517 \\
\hline Kidney & 66.2 & 4.8 & 61.4 & 51.3 & 3.4 & 47.9 & 21.6 & 5.7 & 15.9 \\
\hline Lung & 104 & 3.0 & 101 & 22.3 & 2.3 & 20 & 25.6 & 3.4 & 22.2 \\
\hline Cerebrum & 53.3 & 2.6 & 50.7 & 41.1 & 2.3 & 38.8 & 14.8 & 3.2 & 11.6 \\
\hline Cerebellum & 43.2 & 2.1 & 41.1 & 3.6 & 1.6 & 2.0 & 13.5 & 3.5 & 10 \\
\hline Skeletal muscle & 50.6 & 13.8 & 36.8 & 33.8 & 7.9 & 25.9 & 25.6 & 10 & 15.6 \\
\hline Tail & 12.8 & 6.6 & 6.2 & 7.9 & 3.1 & 4.8 & 15.7 & 11.3 & 4.4 \\
\hline
\end{tabular}

Units are microgram per gram of wet weight 


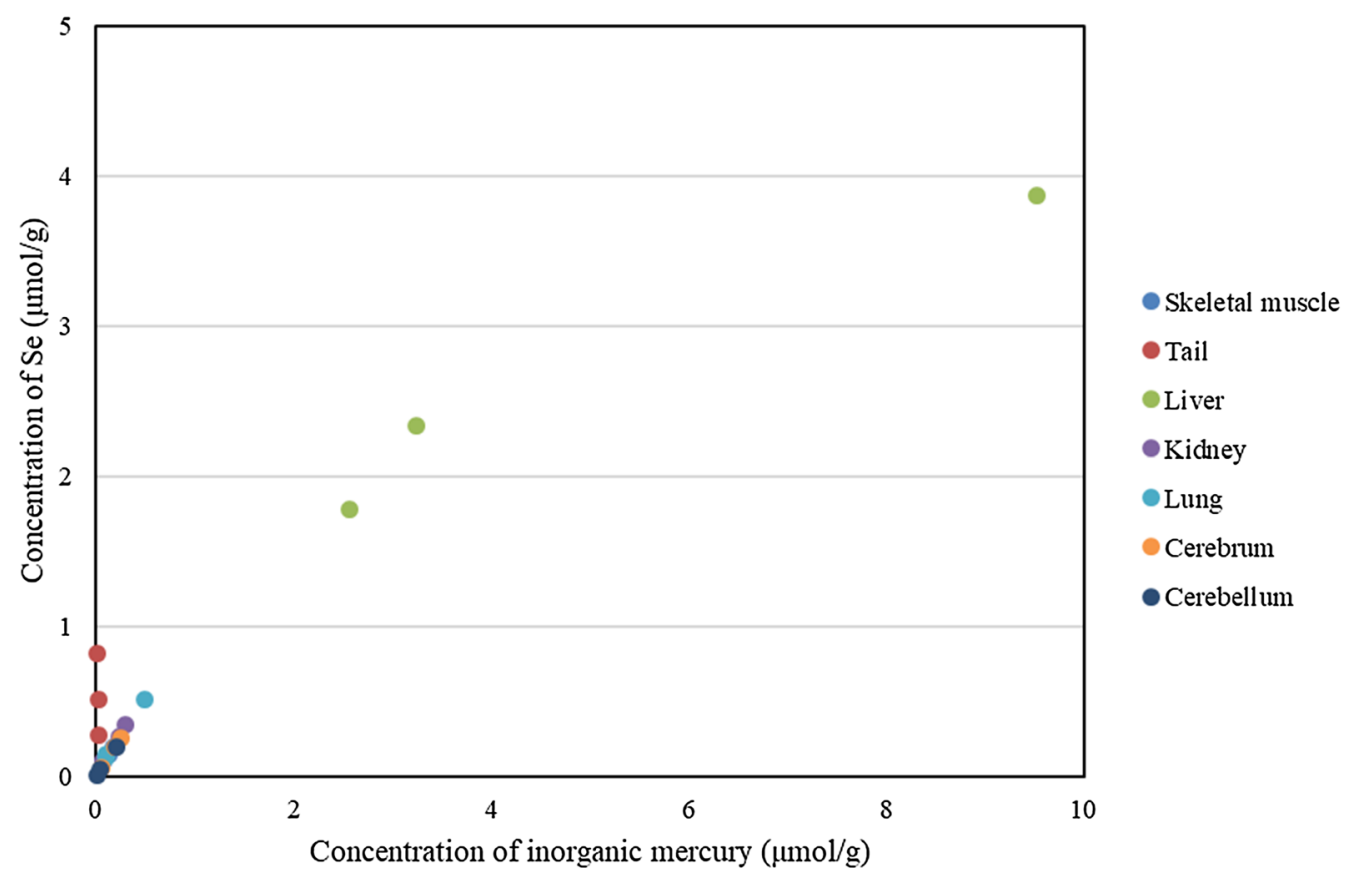

Fig. 1 The relationship between $\mathrm{l-Hg}$ and Se contained in organs is shown. Hg levels in liver are shown to be higher than in other organs

Table 2 Molar ratio of $\mathrm{I}-\mathrm{Hg}$ to $\mathrm{Se}$ in tissues from bottlenose dolphins

\begin{tabular}{llll}
\hline & Case 1 & Case 2 & Case 3 \\
\hline Liver & 2.46 & 1.39 & 1.45 \\
Kidney & 0.89 & 0.90 & 0.72 \\
Lung & 0.98 & 0.78 & 0.74 \\
Cerebrum & 1.00 & 1.00 & 1.07 \\
Cerebellum & 1.04 & 0.93 & 0.96 \\
Skeletal muscle & 0.93 & 0.9 & 0.83 \\
Tail & 0.06 & 0.08 & 0.02 \\
\hline
\end{tabular}

(Fig. 4). Figure 5 shows a compositional image of the kidney in backscattered electron mode, showing deposition of white fine granules on the glomerular capillary wall and the interstitium. Energy-dispersive spectroscopy showed the granules to be composed of $\mathrm{Hg}$ and Se (data not shown). Fine white granules suggesting metal deposition were observed in the interstitium but not in the renal tubules (Fig. 5). Elemental mapping at the same site identified the elements deposited in the glomeruli as $\mathrm{Se}$ and $\mathrm{Hg}$ (Fig. 5). Metals were also observed in the large and small blood vessel walls of the kidney. In the lung,
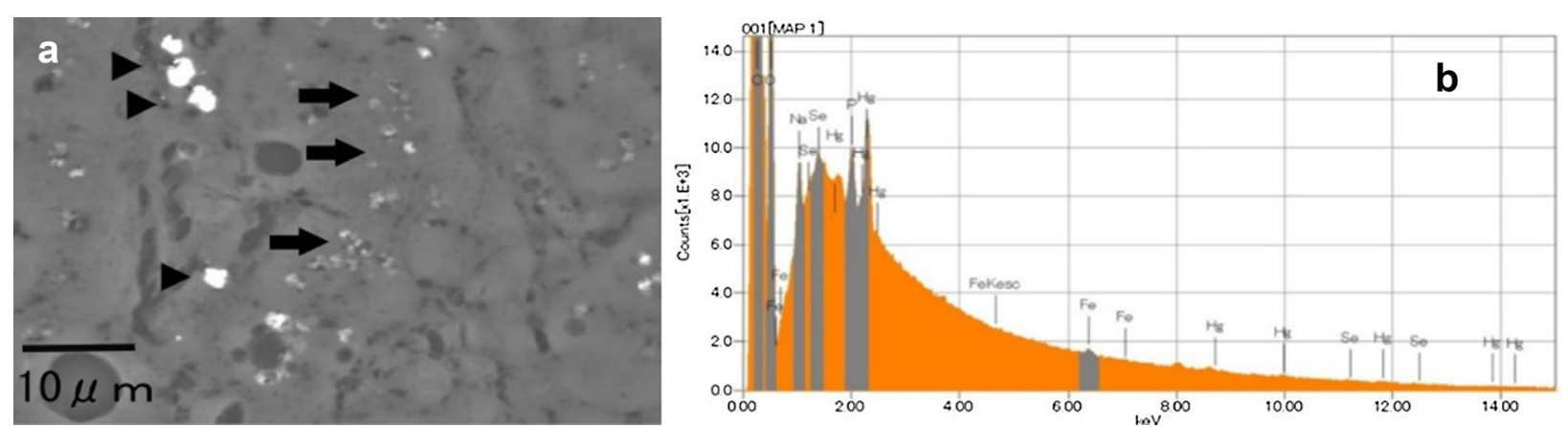

Fig. 2 a Compositional image in backscattered electron mode of white granular materials, indicating element aggregation in hepatocytes (arrows) and Kupffer cells (arrowheads) of the liver. $\mathbf{b}$ Energy-dispersive X-ray spectroscopy showed that these white granules contained $\mathrm{Hg}$ and Se 

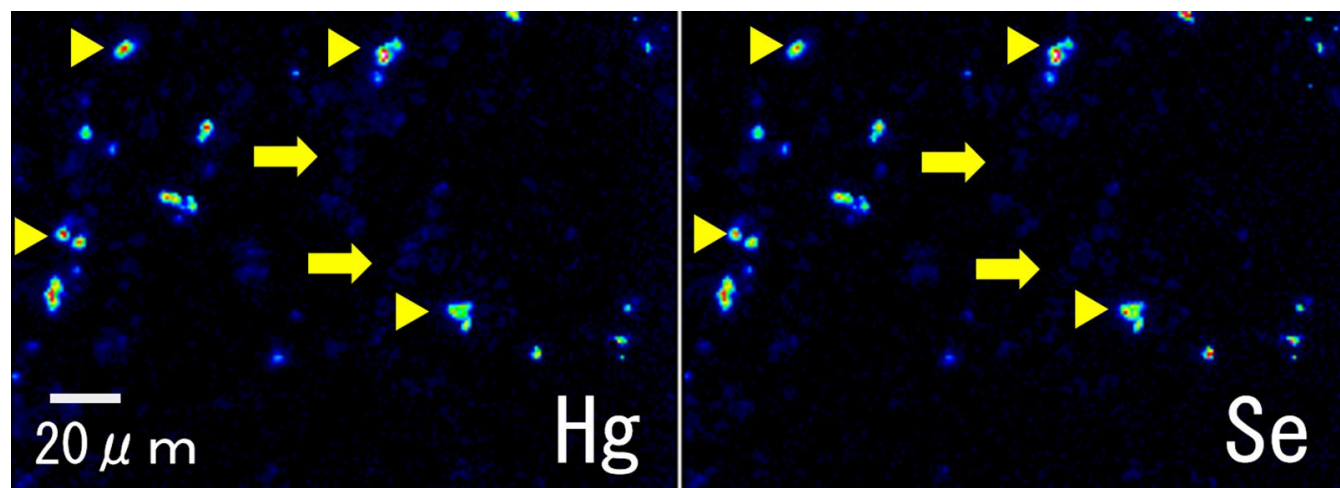

Fig. 3 Elemental mapping of mercury $(\mathrm{Hg})$ and selenium (Se) deposited in hepatocytes (arrows) and Kupffer cells (arrowheads) of the liver. The distribution of these two elements was almost identical. Higher concentrations of $\mathrm{Hg}$ and Se were observed in Kupffer cells than in hepatocytes
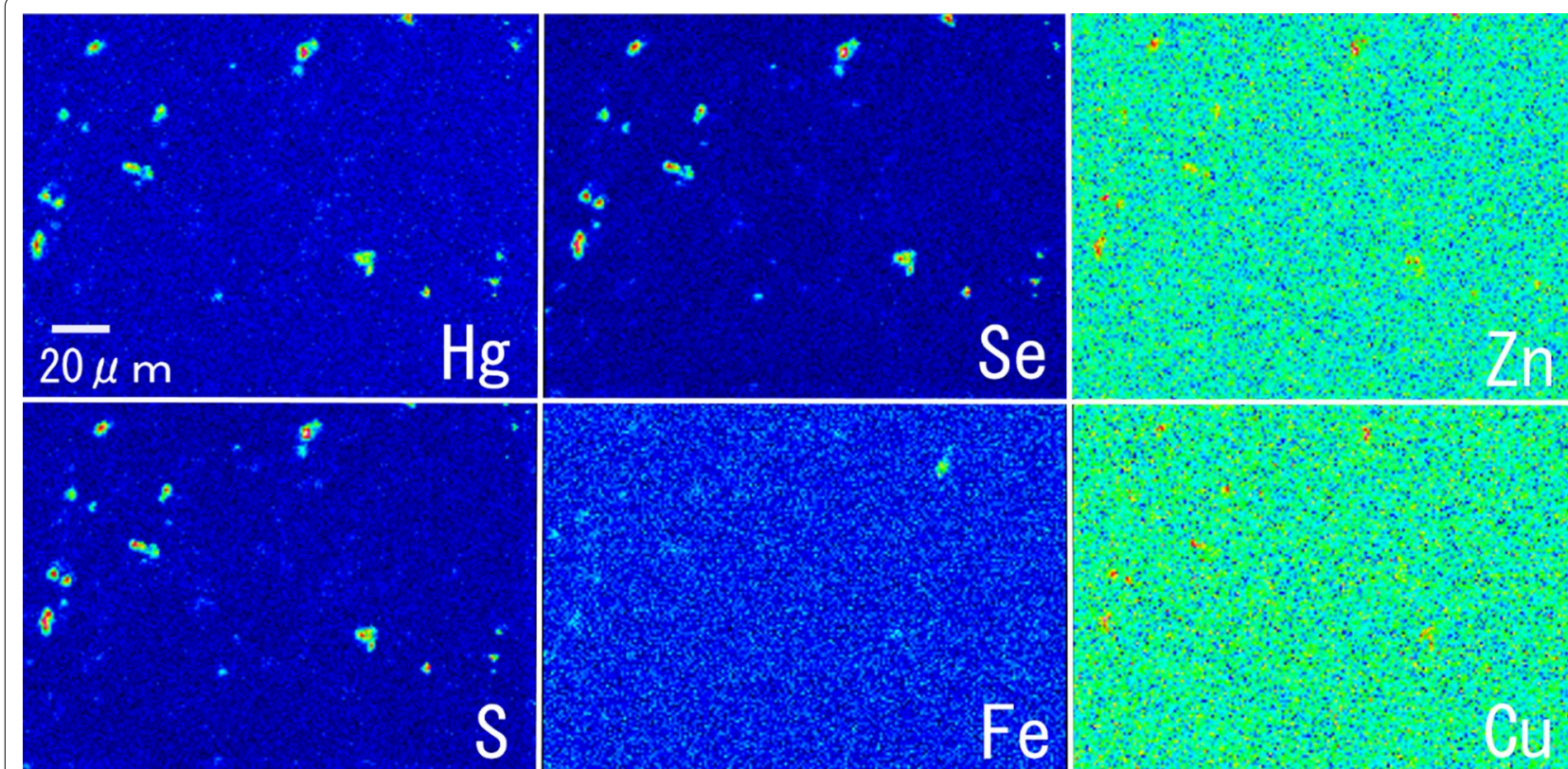

Fig. 4 Elemental mapping identified deposits of mercury (Hg), selenium (Se), zinc ( $\mathrm{Zn})$, sulfur (S), iron (Fe), and copper (Cu) in Kupffer cells of the liver

fine granules were identified as $\mathrm{Hg}$ and Se, suggesting element accumulation in the interstitial but not in alveolar macrophages. In the cerebrum, $\mathrm{Hg}$ and Se were observed in glial cells and the cytoplasm of large neurons. Figure 6 shows electron probe microanalysis mapping and overlap of nitrogen, phosphorus, and $\mathrm{Hg}$; $\mathrm{Hg}$ deposition in the cytoplasm of cerebral large neurons was observed. Figure 7 shows electron probe microanalysis mapping and overlap of phosphorus, $\mathrm{Hg}$, and $\mathrm{Se}$; the images indicate the relative distribution of $\mathrm{Hg}$ and $\mathrm{Se}$, which were colocalized (light blue granules), suggesting that they were present as mercury selenide (HgSe). In the cerebellum,
$\mathrm{Hg}$ and Se were observed in glial cells. In the tail, no $\mathrm{Hg}$ or Se was observed. In skeletal muscle, $\mathrm{Hg}$ and Se were deposited around the nucleus.

When $\mathrm{MeHg}$ is demethylated in hepatocytes and it is converted to $\mathrm{I}-\mathrm{Hg}$, it cannot pass easily through the brain-blood barrier [19]. However, we found $\mathrm{Hg}$ and Se in neurons and glial cells, and presume that these cells perform demethylation in the dolphin brain. Considering the observed absence of $\mathrm{MeHg}$ poisoning in dolphins [19], our results suggest that this feature may be attributable to a high demethylation capacity in the brain. Aggregation of $\mathrm{HgSe}$ was previously reported 


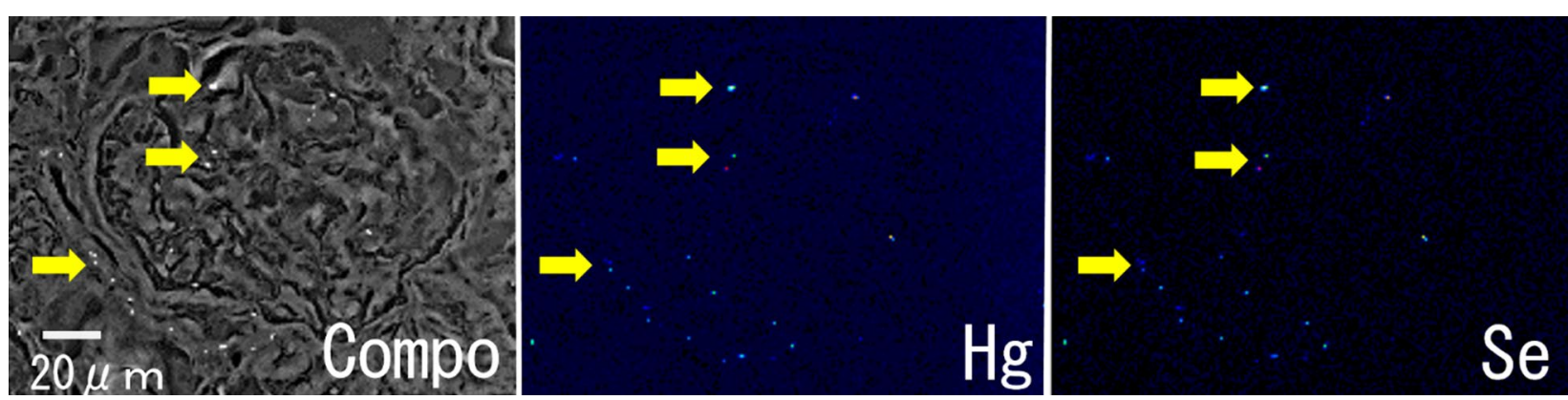

Fig. 5 Compositional image in backscattered electron mode (Compo) of white granular materials in the kidney, indicating element aggregation in the glomerular walls and the interstitium (arrows). Elemental mapping shows the aggregation of mercury (Hg) and selenium (Se), which were co-localized
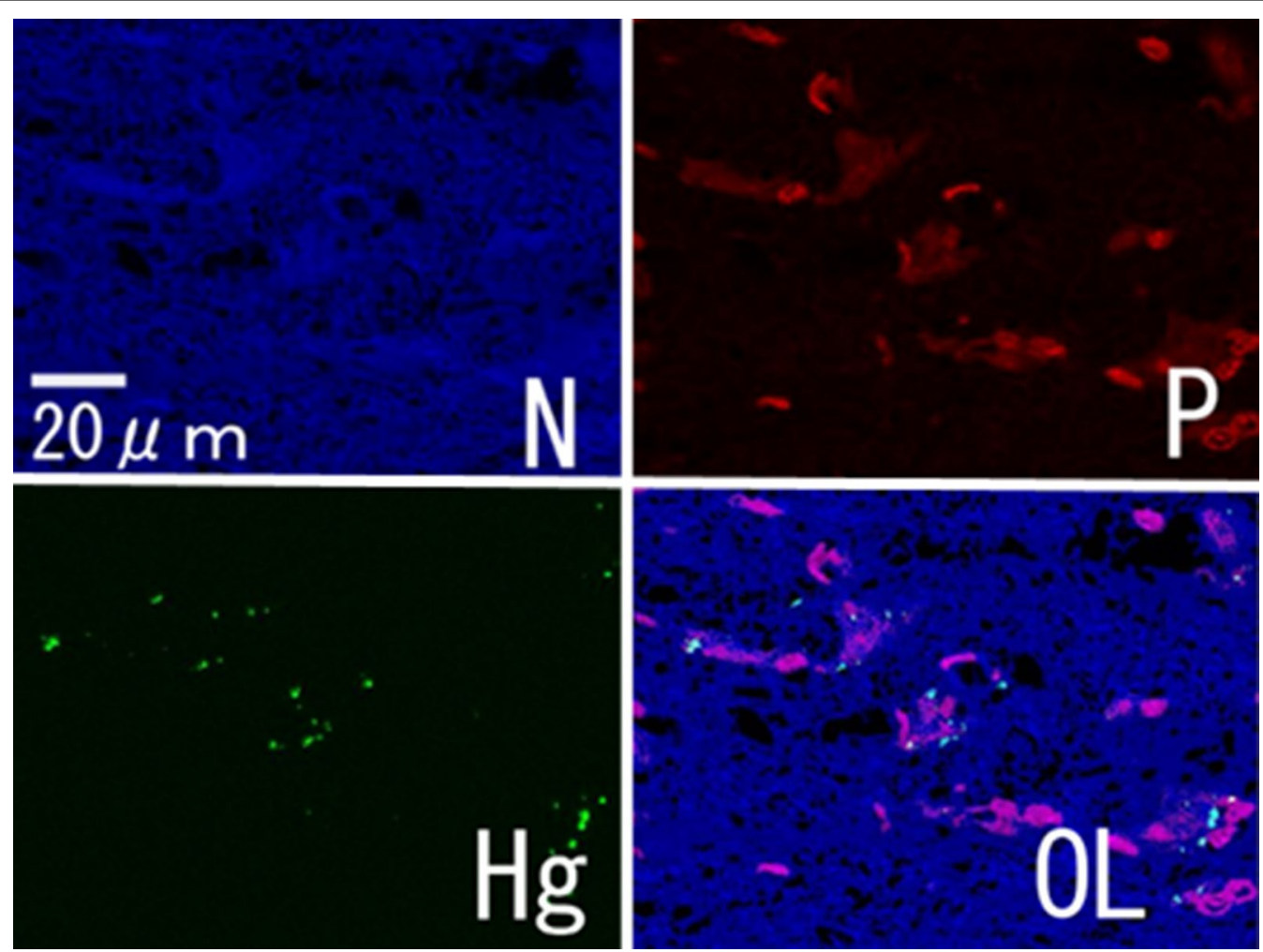

Fig. 6 Electron probe microanalysis mapping of nitrogen $(\mathrm{N})$, phosphorus (P), mercury $(\mathrm{Hg})$, and an overlapping $(\mathrm{OL})$ image in the cerebrum. $\mathrm{Hg}$ deposition in the cerebrum was observed in the cytoplasm of large neurons (light blue granules in the OL image)

in Kupffer cells from dolphins [7]. Kupffer cells are derived from bone marrow monocytes and contain numerous lysosomes and phagocytic matter; they act as macrophages to remove bacteria and phagocytose substances metabolized in hepatocytes. In this study, we found S co-localized in Kupffer cells with $\mathrm{Hg}$ and Se. S is present in various cells in vivo, and has high affinity to metals. Kupffer cells typically contain other metals that can bind to $\mathrm{S}$, but Se has a higher affinity to $\mathrm{Hg}$ than to $\mathrm{S}[20]$, suggesting that excess $\mathrm{Hg}$ that could not be bound to Se may be bound to sulphur in Kupffer cells. We did not find $\mathrm{Hg}$ and $\mathrm{Se}$ in alveolar macrophages and other phagocytic cells, with the exception of Kupffer cells. This suggests that only hepatocytes retain the demethylation function, and Kupffer cells only phagocytize local and demethylated $\mathrm{Hg}$ and Se. 

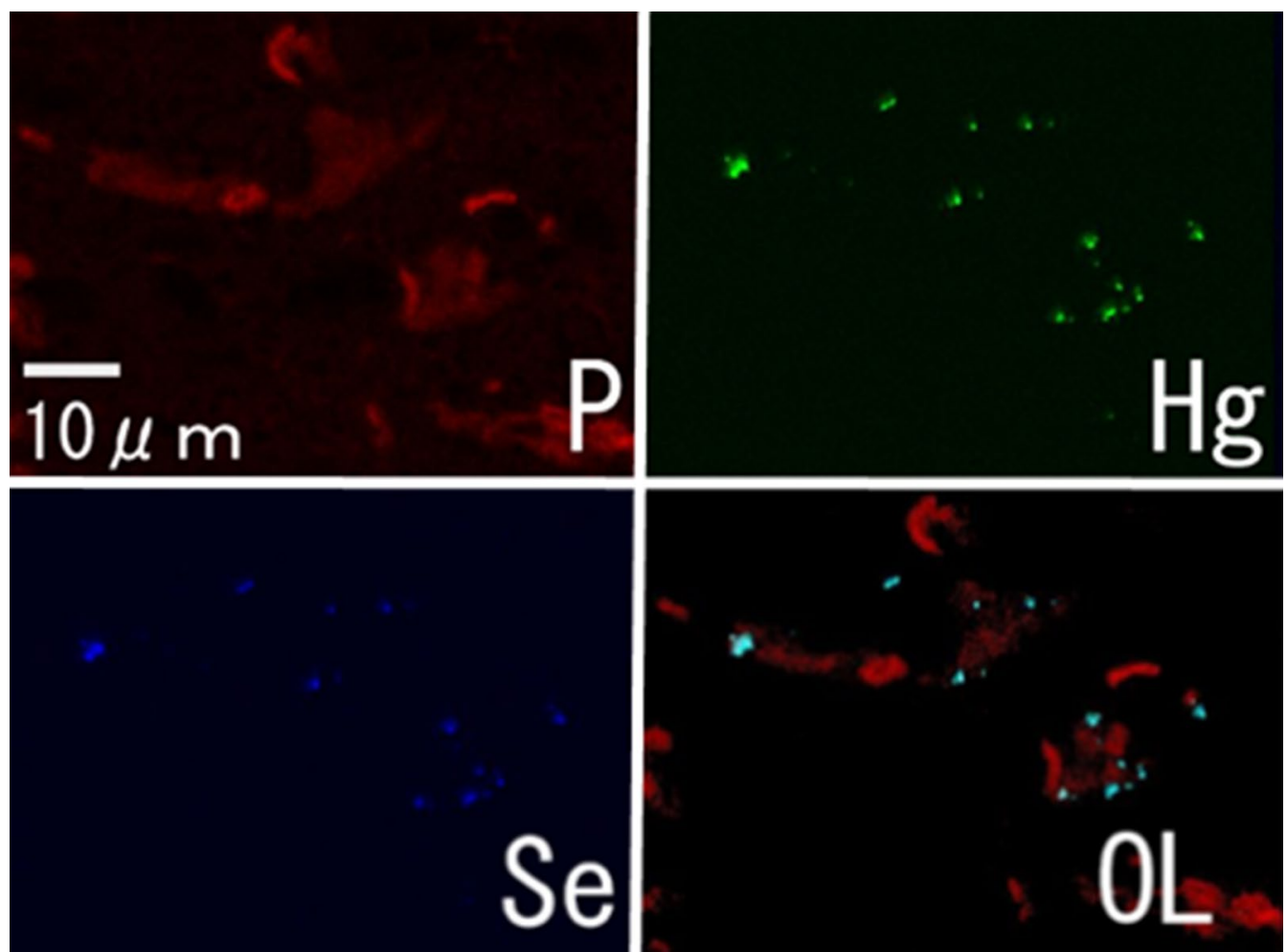

Fig. 7 Electron probe microanalysis mapping of phosphorus (P), mercury ( $\mathrm{Hg})$, selenium (Se), and an overlapping (OL) image in the cerebrum. $\mathrm{Hg}$ and Se were co-localized in the cerebrum (light blue granules in the OL image)

In the lung and kidney, $\mathrm{Hg}$ and Se were observed in the interstitium and blood vessel walls. In contrast, in humans exposed to $\mathrm{MeHg}, \mathrm{Hg}$ and Se are deposited in the proximal and distal tubules of the kidney [12]. Therefore, the observed differences between dolphins and humans may indicate differences in $\mathrm{Hg}$ and Se deposition among distinct mammalian orders, although we tested organs from only one dolphin. In skeletal muscle cells, $\mathrm{Hg}$ and Se were deposited around the nucleus. Because of the abundance of mitochondria around the nucleus, mitochondrial demethylation may occur, and electron microscopy is required to test this hypothesis.

We showed that Se and $\mathrm{Hg}$ are co-localized not only in liver and kidney but also in other organs such as brain, skeletal muscle and lung. This suggests cellular demethylation of $\mathrm{MeHg}$ and binding of $\mathrm{I}-\mathrm{Hg}$ to $\mathrm{Se}$ to form HgSe throughout the body, promoting further accumulation of $\mathrm{Hg}$ and $\mathrm{Se}$.

\section{Acknowledgements}

The authors are grateful to Dr. Yoshifumi Takahashi, Nanae Ryuzaki, and Satsuki Nagase, Department of Dental Material Science, Dentistry School of Aichi Gakuin University, Nagoya, Japan, and thank Mao Uchikakoi, Miwa Chijiiwa, and Ai Motoyama, National Institute for Minamata Disease. The authors thank Edanz Group (https://en-author-services.edanzgroup.com/ac) for editing a draft of this manuscript.

\section{Authors' contributions}

MM and MS designed the study; MM, KM, and ST acquired, analyzed, and interpreted the data; MM drafted the manuscript; MS, KM, ST, and MN critiqued and revised the manuscript. All authors approved the final draft and agreed to be accountable for all aspects of the work, to ensure that questions relating to the accuracy or integrity of any part of the work would be appropriately investigated and resolved. All authors read and approved the final manuscript.

\section{Funding}

This research was funded by JSPS Research Grant JP23510085. The study was co-funded by the National Institute for Minamata Disease.

\section{Availability of data and materials}

The datasets used and analyzed during the current study are available from the corresponding author upon reasonable request.

\section{Declarations}

Ethics approval and consent to participate

This study did not require official or institutional ethical approval. The specimens from the test animal were handled according to high ethical standards and national legislation.

\section{Consent for publication}

Not applicable.

\section{Competing interests}

The authors declare that they have no competing interests with respect to the research, authorship, and publication of this article. 


\section{Author details}

${ }^{1}$ National Institute for Minamata Disease, 4058-18, Hama, Minamata, Kumamoto 867-0008, Japan. ${ }^{2}$ Department of Dental Material Science, School of Dentistry, Aichi Gakuin University, 1-100 Kusumoto-cho, Chikusa-ku, Nagoya, Aichi 464-8650, Japan.

Received: 20 December 2020 Accepted: 4 October 2021 Published online: 27 January 2022

\section{References}

1. Endo T, Haraguchi K, Sakata M. Mercury and selenium concentrations in the internal organs of toothed whales and dolphins marketed for human consumption in Japan. Sci Total Environ. 2002;300:15-22.

2. Endo T, Haraguchi K, Hotta Y, Hisamichi Y, Lavery S, Dalebout M, et al. Total mercury, methyl mercury, and selenium levels in the red meat of small cetaceans sold for human consumption in Japan. Environ Sci Technol. 2005;39:5703-8.

3. Leonzio C, Focardi S, Fossi C. Heavy metals and selenium in stranded dolphins of the northern Tyrrhenian (NW Mediterranean). Sci Total Environ. 1992;119:77-84.

4. Itano K, Kawai S, Miyazaki N, Tatsukawa R, Fujiyama T. Mercury and selenium levels in striped dolphins caught off the Pacific coast of Japan. Agric Biol Chem. 1984;48:1109-16.

5. Ralston NV, Ralston CR, Blackwell JL 3rd, Raymond LJ. Dietary and tissue selenium in relation to methylmercury toxicity. Neurotoxicology. 2008;29:802-11.

6. Koeman JH, van de Ven WS, de Goeij JJ, Tjioe PS, van Haaften JL. Mercury and selenium in marine mammals and birds. Sci Total Environ. 1975:3:279-87.

7. Lailson-Brito J, Cruz R, Dorneles PR, Andrade L, Azevedo Ade F, Fragoso $A B$, Vidal LG, et al. Mercury-selenium relationships in liver of Guiana dolphin: the possible role of Kupffer cells in the detoxification process by tiemannite formation. PLoS ONE. 2012;7(7):e42162.

8. Sakamoto M, Itai T, Yasutake A, Iwasaki T, Yasunaga G, Fujise Y, et al. Mercury speciation and selenium in toothed-whale muscles. Environ Res. 2015;143:55-61.

9. Nakazawa E, Ikemoto T, Hokura A, Terada Y, Kunito T, Tanabe S, et al. The presence of mercury selenide in various tissues of the striped dolphin: evidence from $\mu$-XRF-XRD and XAFS analyses. Metallomics. 2011:3:719-25.
10. Cáceres-Saez I, Dellabianca NA, Goodall RN, Cappozzo HL, Guevara SR. Mercury and selenium in subantarctic Commerson's dolphins (Cephalorhynchus c. commersonii). Biol Trace Elem Res. 2013;151:195-208.

11. Yang J, Kunito T, Tanabe S, Miyazaki N. Mercury and its relation with selenium in the liver of Dall's porpoises (Phocoenoides dalli) off the Sanriku coast of Japan. Environ Pollut. 2007;148:669-73.

12. Sakai $K$, Okabe M, Eto K, Takeuchi T. Histochemical demonstration of mercury in human tissue cells of Minamata disease by use of autoradiographic procedure. Acta histochem cytochem. 1975;8:257-64.

13. Danscher G, Møller-Madsen B. Silver amplification of mercury sulfide and selenide: a histochemical method for light and electron microscopic localization of mercury in tissue. J Histochem Cytochem. 1985;33:219-28.

14. Kobayashi M, Watanabe K, Miyakawa O. A new sampling technique to obtain the elemental mapping of a bio-tissue section by means of the EPMA equipped with WDX. Niigata Dent J. 1996;26:29-37.

15. Watanabe K, Kobayashi M. How do we analyze the metallic element distribution in tissue section? New application of element mapping by EPMA. J Surf Sci Soc Jpn. 2001;22:332-6.

16. Takada T, Moriyama H, Suzuki E. Elemental analysis of occupational and environmental lung diseases by electron probe microanalyzer with wavelength dispersive spectrometer. Respir Invest. 2014;52:5-13.

17. Marumoto M, Sakamoto M, Marumoto K, Tsuruta S, Komohara Y. Mercury and selenium localization in the cerebrum, cerebellum, liver, and kidney of a Minamata disease case. Acta histochem cytochem. 2020;53:147-55.

18. Akagi H, Castillo ES, Cortes-Maramba N, Francisco-Rivera AT, Timbang TD. Health assessment for mercury exposure among schoolchildren residing near a gold processing and refining plant in Apokon, Tagum, Davao del Norte, Philippines. Sci Total Environ. 2000;259:31-43.

19. World Health Organization; International Program on Chemical Safety. Environmental Health Criteria 101, Methylmercury. Geneva: World Health Organization; 1990

20. Sugiura Y, Hojo Y, Tamai Y, Tanaka H. Selenium protection against mercury toxicity. Binding of methylmercury by the selenohydryl-containing ligand. J Am Chem Soc. 1976;98:2339-41.

\section{Publisher's Note}

Springer Nature remains neutral with regard to jurisdictional claims in published maps and institutional affiliations.
Ready to submit your research? Choose BMC and benefit from:

- fast, convenient online submission

- thorough peer review by experienced researchers in your field

- rapid publication on acceptance

- support for research data, including large and complex data types

- gold Open Access which fosters wider collaboration and increased citations

- maximum visibility for your research: over $100 \mathrm{M}$ website views per year

At BMC, research is always in progress.

Learn more biomedcentral.com/submissions 